\title{
The Condition Which Is Contained in Grammatical Rule
}

\author{
Enad Mukhlif Muhabbsh AL-Heety \\ College of Islamic Science, University of Anbar, Iraq \\ enad.mukhlef@uoanbar.edu.iq
}

\begin{abstract}
:
The grammatical rule is considered the final model that will be followed construct a meaningful sentence as Arabic used to say. This rule has certain limits that governs the grammatical rule in order not to be confused with another .one of these limits is the condition put by grammarians which is considered an important limit. The condition is also regarded a must to the rule although it is not shared in governing it. Yet, if it is absent, there will not be a grammatical rule. The condition will be very essential if we have similar grammatical rules and it becomes important to put more than one condition to differentiate among these rules for this reasons, the condition is important for the grammarians.
\end{abstract}

Keywords: $\quad$ Condition; Contained; Rule; Grammatical; Boundary.

Crossref doi https://doi.org/10.51345/.v31i2.203.g167 


\section{الشرط الذي يرد على القاعدة النحوية \\ د. عناد مخلف مهبش حسن الميتي \\ كلية العلوم الإسلامية، جامعة الانبار، العراق \\ enad.mukhlef@uoanbar.edu.iq}

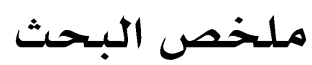

تُعَد القاعدة النحوية القالب النهائي الذي يُحتَّى به في إنشاء جملة مفيدة على سنن العرب في كلامها، وهذه القاعدة حُدّدت بمحددات تكون ضوابط تنضبط بها القاعدة النحوية؛ حتى لا تلتبس بقاعدة أخرى، ولا يدخل على القاعدة ما كان خارجًا عنها، ولا يخرج ما كان داخلاً فيها، ومن هذه الضوابط الشرط الذي وضعه النحاة، فهو قيد مهمّ من القيود، ويُعدّ الشرط لازمًا من لوازم القاعدة، وإن لم يكن مشاركًا في الحكم ولا من موجباته، لكن يلزم من عدمه العدم، فإن عُدِم الشرط عُدِمِت القاعدة

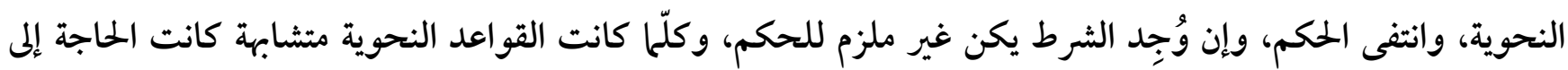
وضع أكثر من شرط للتفريق بينها، ولمذا الشرط أثر كبير في اختلاف النحاة، وهنا تظهر أهميته عندهم. 
المقدمة

الحمد لله رب العالمين على جميع نعائه، على ما أنعم به علينا وجعلنا من عباده، والصلاة و السلام على صفوة أنبيائه محمد وعلى آله وأصحابه، ومن اتبعهم، ووالاهم. وبعد: فإنّ النحو العربي كلّه مبني على القواعد التي أُخِذت من كلام العرب أو ما قيس على كلامهم، وعند تقعيد القو اعد النحوية، وتأصيلها، ظهرت كثيرٌ من قو اعده متشابهة، فكان لا بدّ من إيباد بعض الطرائق وصولًا إلى التمييز بين القواعد المتشابهة، والحيل؛ لتتميّز كلّ قاعدة عن غيرها، وتستقلّ بنفسها، فوضعوا نوعين من المميزات بين القواعد، أحدهما خارجي ومنه موضوع البحث هذا، والآخر داخلي. والشرط أحد القيود الخارجة عن القاعدة ولا يدخل فيها بشيء، ولا تأثير له على أيّ حكم نحوي، مها كان بسيطًا أو معقًّاً، وتظهر فائدته في بيان الفرق بين قاعدتين متشابهتين أو أكثر، وبعد جمع الشروط التي وردت على القواعد النحوية، وجدت أنّ كثيرًا منه لابدّ من الوقوف عليه وقفة مستفيضة، وإن كانت كلّ الشروط التي وُضِعت لا تقلّ أهمية عن المختارة في هذا البحث. واقتضت طبيعة البحث أن أقسّمه على مبحثين: أحدها: فائدة الشرط، والآخر: المو اضع التي جاء فيها شرط أو أكثر، وتسبقها هذه المقدمة، ومن ثَمّ التمهيد، وذكرت فيه تعريف الشرط ومفهو مه، وبعد المبحثين ذكرت الخاتمة وهو امش البحث وقائمة المصادر المستعملة في البحث. وفي الختام أقول: إنّ هذه المحاولة في كتابة الشرط الذي يرد على القاعدة النحوية كانت محاولة جادّة توقفت في كتب النحاة، وأسأل الله تعالى أن أكون قد وُفقِت في هذا العمل، والحمد لله في الأولى والآخرة، والصلاة و السلام على رسوله وعلى آله وأصحابه. 


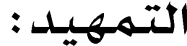

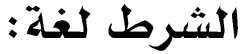

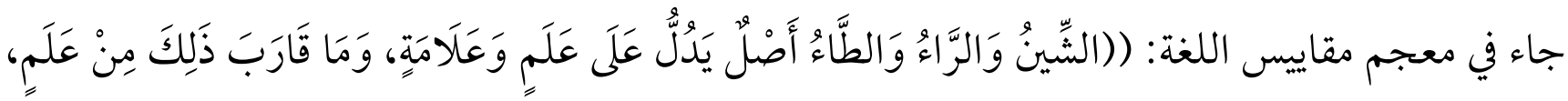

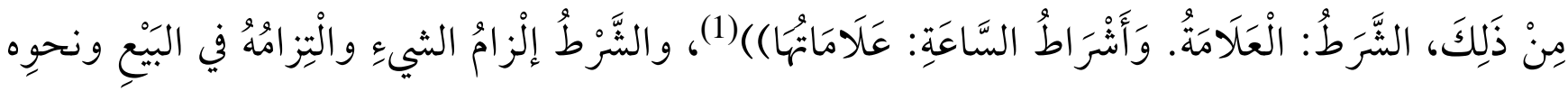

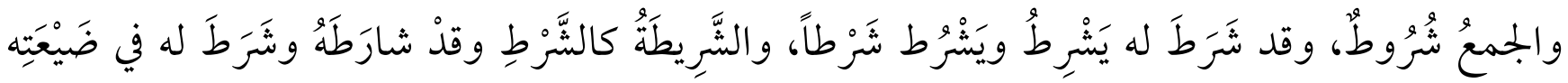

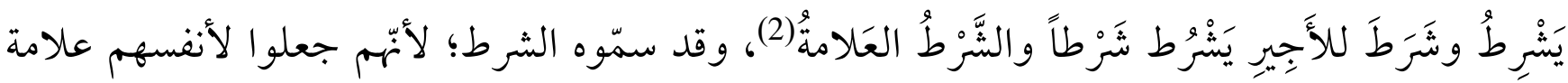
يعرفون بها(3)، وفي اللسان: الشَّرّ: إلزام الشيء والتزامه في البيع وغيره(4).

\section{الشرط اصطلاحسًا : الشئ}

يكاد علماء الشريعة من أصوليين وفقهاء يُجمعون على تعريف واحد في مفهوم الشرط وحدّه وإن اختلفت ألفاظهم، إلاّ في نقطة خلاف بسيطة بين الأصوليين والفقهاء على ما سيأتي إن شاء الله تعالى، والتعريف الذي يجمعون عليه أنّ الشرط هو: ((ما يلزم من عدمه العدم و لا يلزم من وجودهه وجود ولا عدم))(5)، أو: ((هو ما يُضاف إليه الحلكم وجودًا لا وجوبًا به)(6)، وهذان التعريفان يفيدان أنّ الشرط لا علاقة له بوجوب الحكمى، ولا يرتفع إلى منزلة العلّة، فُدّعىى أنّه هو الذي اقتضى الحكم، ويلزم من وجوده وجود الحلكم، لكن ينتفي الحلكم بانتفائه، مثال ذلك، الشرط في التمييز أن يكون استًا، فإذا انتفت الاسمية انتفى كونه تمييزًا، لكن شرط الاسمية ليس علامة على أنّ كلّ اسم نعربه تمييزًا. وهذا القيد الذي وُضِع على القواعد يكون خارجًا عنها، ويُعبر عنه أحيانًا بأنّه خارج عن ماهية القاعدة أو العلّة، بمعنى: أنّ الشرط قيد يوضع على القواعد للتمييز بين المتشابه منها، ولا يفرّق في كثير منها إلا بوضع أكثر من شرط أحيانًا حتى تتميز قاعدة من أخرى، ومن الامثلة على ذلك ما انتصب لشبهه بالمفعول أو بها في معناه، كالتمييز والحال المفردة، فإنها اسمان ومنصوبان، قال ابن يعيش: ((التمييز يُشِبه الحالَ؛ وذلك أنّ كل واحد منها يُذكر للبيان، ورفع الإبهام)(7)، والحال المفردة تكون منصوبة؛ لمِا في الحال من معنى المفعولية، وهذه العلّة لازمة في كلّ حال مفردة، في كل موضع لكن يُشترَط في الحال المنصوبة أن تكون نكرة متنقلة 
ومشتقة على رأي البصريين(8)، أمّا التمييز فقد حدّد شروطه ابن مالك بقوله: ((وحُدِّد جرّه بها فيه معنى (من) احترازًا من الحال فإنهّا تشاركه فيها سوى ذلك من القيود، وقيدت بالجنسية ليخرج ما فيه معنى (مِن) وليست جنسية... وقيدت التمبيز بنكرة احترازًا من المعرفة المنتصبة على التشبيه بالمفعول به في نحو: حسن وجهَله، فإنّ فيه ما في حسن وجهًا إلا التنكير، فبذلك افترقا ولم ينتصبا من وجه واحد، وذكر النصب احترازًا من النكرة المضاف إليها وفيها معنى من الجنسية نحو: له رطل زيتِّ، وخرج بفضلة اسم (لا) المحمولة على (إنّ)، نحو: لا خير من زيد فيها، فإنّ فيه ما في التمييز إلا الفضلة ففيه ضدها، وخرج بغير تابع ما جعل تابعًا للعدد من جنس المعدود))(9)، وهذه الشروط لا يمكن أن نعدّها العلل الموجبة لنصب الحال، أو و احدة منها، وكذلك الشروط في نصب التمييز، لكن ينعدم إعرابها حالًا أو تمييزًا أن فقدتا أحد هذه الشروط. أمّا الشرط في عرف الفقهاء فهو: ((ما يلزم من انتفائه انتفاء الشيء الذي جعل شرطًا فيه مع أنّه ليس بمقوم له فعدمه حينئ علامة على النفي))(10)، و القيد الذي اختلفوا فيه مع الاصوليين هنا، (أنّه ليس بمقوم)، أي: لا

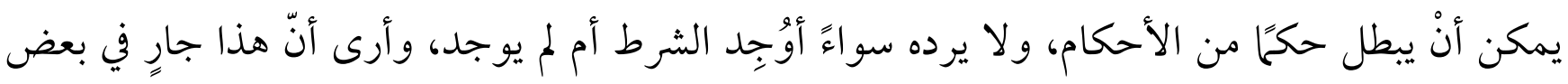
الأحكام الواجبة لا الجائزة، وهنا سيشترك نوعان من الشروط أحدها هذا المذكور، والآخر شروط من قبيل الأسباب، والتمثيل عليه بمسألة فقهية يخرج البحث عن مساره النحوي. وبالعودة إلى الشرط و الفائدة من حدّ الاصوليين يُفهم من قولهم في اللزوم وعدمه، أنّ الشرط لا يُلزِم القاعدة في شيء؛ لأنّه لا يلزم من وجود الشرط وجود المشروط، فالشرط قد يوجد لكنّه غير مُلزِم كوجود اسم نكرة مشتق لكن لا يمكن أن نعدّه حالًا، ولا من انتفاء المشروط انتفاء الشرط كوجود الحال في الجملة لكنّه ليس اسمًا مفردًا وليس نكرة ولا مشتقًا لكنّه جملة، فقد انتفت الشروط لكن بقي الإعراب حالًا؛ لكونه جملة، ومتى جُعِل شيء لازمًا لشيء يجب أن يكون اللازم أعمّ من الملزوم، أو مساوياً له، وثبوت الاخصّ يوجب ثبوت الاعمّ، و انتفاء الاعمّ يوجب انتفاء الاخصّ، ولا يلزم العكس (11). وكذلك المراد بقولهم: (ولا عدم لذاته)، في تعريف بعض الاصوليين، وهو: ((ما يلزم من عدمه العدم، ولا يلزم من وجوده وجود ولا عدم لذاته)(12)، احترازًا به عن مقارنة الشرط وجود السبب، فيلزم الوجود، أو 
مقارنة قيام المانع، فيلزم عدم الوجود، لكن لا لذاته، بل لأمر آخر خارجي، وهو مقارنة السبب، أو قيام المانع،

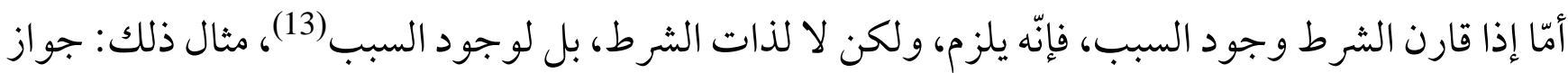

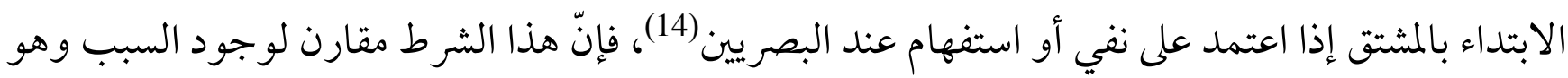
الاعتماد، والشرط قائم على السبب عندهم هنا، فلو زال الاعتماد هنا لم يكن صحيحًا عند البصريين، لكنّهم لم لم

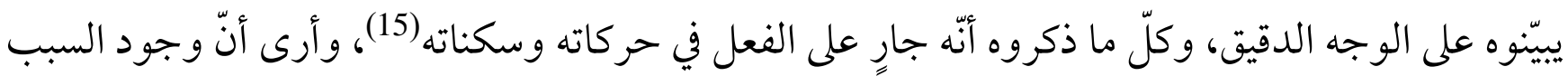

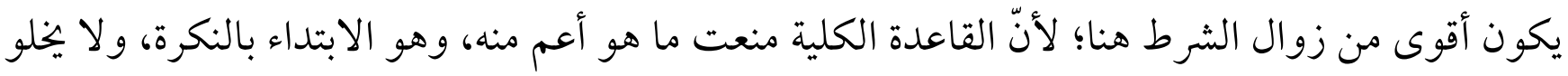
(قائم) في قولنا: قائم زيد، من التنكير، وقد سُمّيت النكرة بمعنى الفعل، قال ابن الصائغ: ((وإذا كانت النّكرة

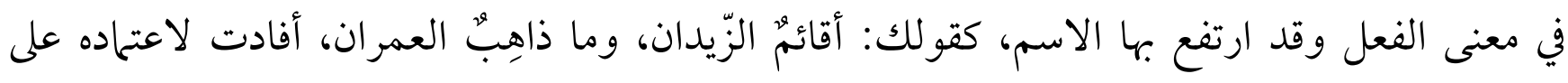
(الاستفهام)(16) (16)

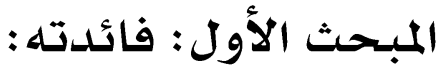

في القو اعد التي يدخل عليها شرط واحد تكون في الغالب قو اعد مستقلة لا تحتاج إلى وسم يسمها حتى تنماز عن غيرها من القواعد، و أغلب هذه الشروط جاءت لتجوّز بعض القو اعد التي يكون المانع فيها قريبًا منها أو

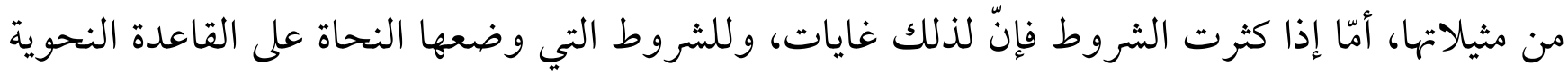

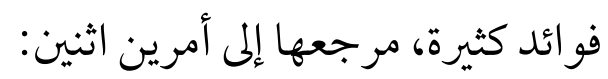

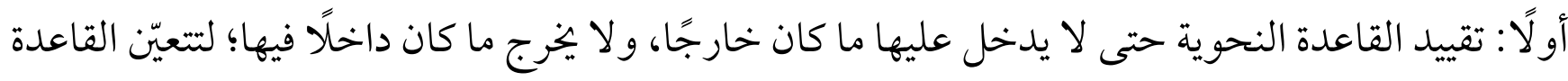
وفصلها عن غيرها، وأكثر ما يكون ذلك في الحدود التي وضعها النحاة، من ذلك حدّ المثنى، إذ: ((هو الاسمّ

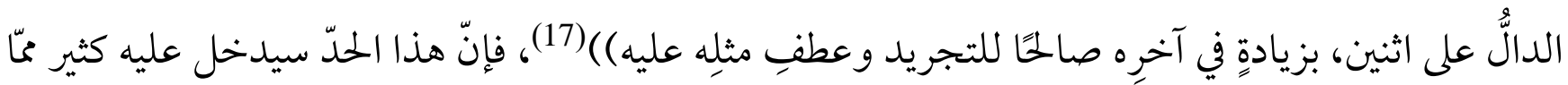

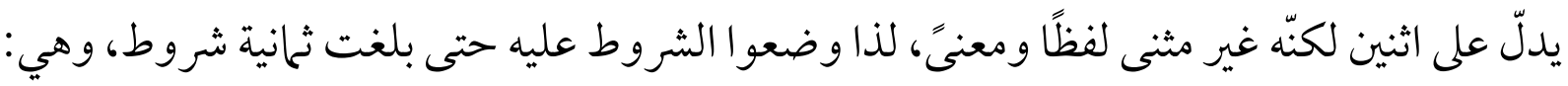

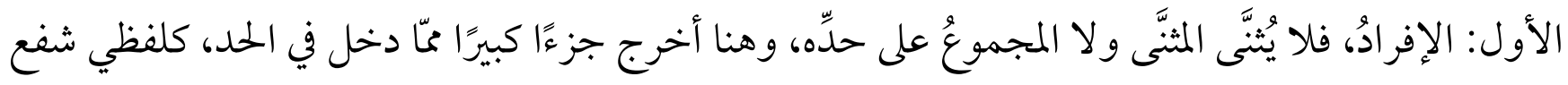

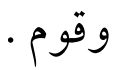


الثاني: الإعراب، فلا يُشنَّى المبني، فقد أخرج المبنيات من الاسماء كلها، وأما نحو: (هذان واللذان) فصيغ"

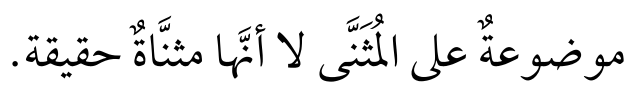

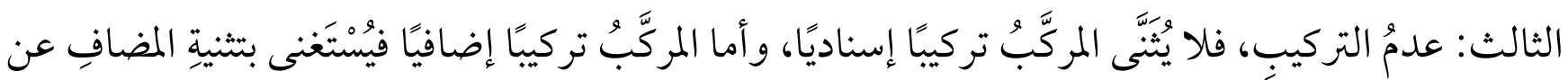

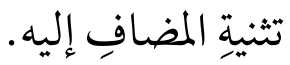

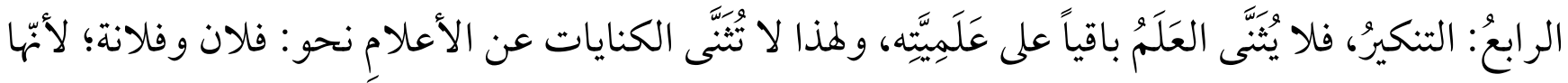
لا تقبلُ التنكير. الخامس: اتفاقُ اللفظ، ك(زيد) و(زيد)، فلا يجوز أن نقول: زيدان، ونقصد باللفظ زيدًا، وعمُرًا.

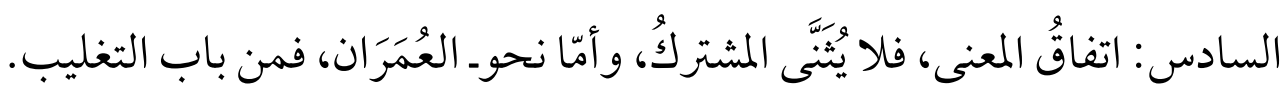

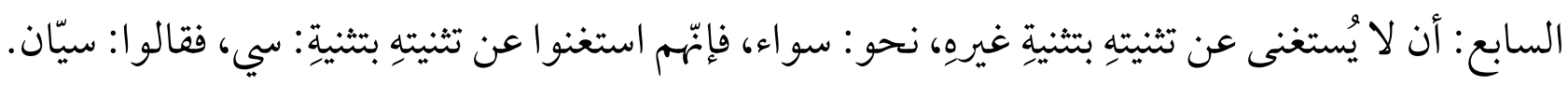

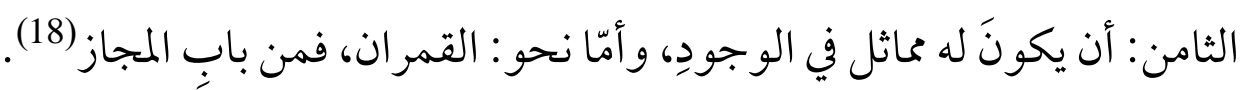

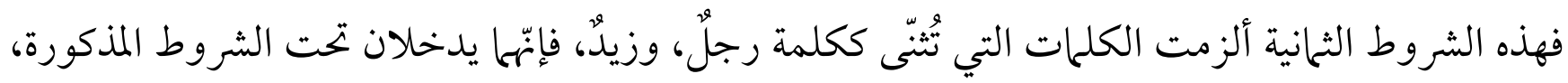

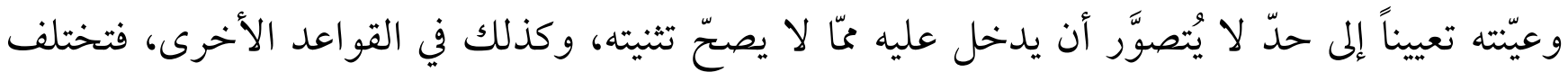
الشروط بحسب وضعها والباب الذي تدخل تحته.

ثانيًا: من أهمّ فوائد الشروط في القاعدة النحوية بيان الفرق بين الاقيسة النحوية، أي: أن يُفرَّق بين قاعدتين نحويتين قبل القياس عليها، وعلى الرغم من كون الشروط هنا بمكان إلا أنّا لا تبدو واضحة جليّة إلا في

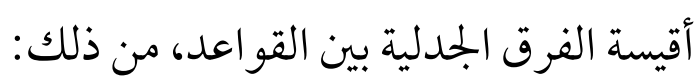

\section{الفرق بين (حتى) العاطفة والجارةّ:}

كي يكون هنا قياس فرق بين (حتى) الجارّة والعاطفة يجب أن يليها اسم، وأمّا إذا جاء بعدها فعل فارة فلا يدخل

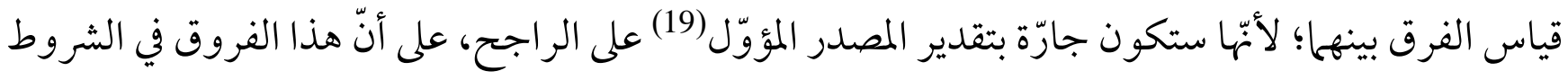
لا علاقة له بقياس الفرق، لكن ذكر هذا المثال هنا لبيان أنّ الشرط كما يدخل في قياس الفرق كذلك يدخل في

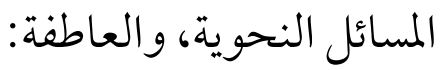




$$
\begin{aligned}
& 1 \text { - أن يكون ما بعد المعطوف قليلًا بعد كثير } \\
& 2 \text { - أن يكون المعطوف جنسًا له } \\
& \text { والجارة: } \\
& 1 \text { - أن يكون المجرور بها ظاهراً } \\
& 2 \text { - أن يكون المجرور آخر جزء، أو ملاقي آخر جزء. } \\
& 1 \text { - أن يكون الإعراب مقدرًا. } \\
& 2 \text { - أن يكون أحدهما له معمو لان. }
\end{aligned}
$$

هذه أهمّ شرطين للفرق بينها، وإلا فهناك شروط أخرى لكل واحدة لا تدخل في بيان الفرق بينها. ومن ذلك: الفرق في وجوب إعراب المقدّم على ترتيب الرتبة من غير تقديم، عند عدم أمن اللبس، وفّرق ابن

وفرّق في هذين الشرطين بين المبتدأ الجائز تقديم خبره عليه وبين الفاعل والمفعول به غير الجائز تقديمه عليه(20)، كقولنا: أخوك رفيقي، وضرب موسى عيسى، فالشرطان ينطبقان على الفاعل والمفعول، لكن لا ينطبقان على المبتدأ والخبر مع عدم ظهور علامة الإعراب في المبتدأ، لكن الوجوب دخل في وجوب تقديم المبتدأ وتأخير الخبر كونها معرفتين، ويُعَد هذا الفرق بسيطًا قياسًا بالفروق الأخرى. ومنها: قاعدة: قد يعمل العامل في الثيء ويمتنع التصرف لنظائره(21)، إذ بحث الكوفيون تحت هذه القاعدة

$$
\begin{aligned}
& \text { العامة: متى يستحقّ الاسم التنوين في التركيب؟ } \\
& \text { يرون أنّه يستحق التنوين بشرطين: } \\
& \text { أحدهما: أن يكون العامل ظاهرًا غير مقدّر. } \\
& \text { والآخر: : أن يكون المعنى النحوي متو افقًا مع العلامة الإعرابية. }
\end{aligned}
$$

وفرقوا بها بين الاسم في قولنا: يا زيدُ، وأنادي زيداً، فامتنع في النداء وتصرّف في المفعول به، وكذلك الاسم المنصوب قبل دخول (لا) النافية للجنس، وبعد دخولها، على أنهم خالفوا البصريين في جعل زيد واسم لا 
معربَين لا مبنيين لكنّها غير مستحقَين للتنوين (22)، على أنّ السيرافي اختار فتحة اسم (لا) النافية للجنس فتحة اعر اب لا فتحة بناء، إذ قال: (والذي عندي: أنّ الفتحة في الاسم بعد (لا) إعراب وهو مذهب سيبويه؛ لأنّه قال: فتنصبه بغير تنوين، ونصبها لما بعدها كنصب (إن) لما بعدها، وترك التنوين لما تعمل فيه لازم (23) ... قد يعمل العامل في الشيء ويمنع التصرف الذي لنظائره ولا يكون ذلك مبطلا لعمله كقولك: حبذا زيد)(24). وكذلك فرّقو ا بالشرط بين بعض القواعد بييان:

\section{شرط المعنى:}

واختاروا نوعين من المعاني، هما: شرط المو افقة في المعنى، و الاشتراك في المعنى. أمّا الأول وهو شرط المو افقة بالمعنى فقد فرّقوا به بين قولنا: زيدُّ قائمّ، وزيدٌ عندَك، فالأول ارتفع - أي: الخبر - لأنّه هو زيد في المعنى (25)، وأمّا الثاني انتصب؛ لأنّه ليس هو في المعنى المبتدأ نفسه، وفيه نظر على ما سيأتي عند البصريين. أمّا الآخر وهو شرط الاشتراك في المعنى فقد فرّقوا بهذا الشرط بين الفعل المضارع المعطوف بالواو أو الفاء، فهذا الاشتراك مكّن الفعل المضارع أن يسبق ما عُطِف عليه من فعل أن يتبعه في الإعراب، وبين الفعل المضارع المسبوق بالواو أو الفاء ولم يشترك في المعنى مع الذي قبله؛ وهذا أوجبو انصبه، ولم تقف المسألة عند هذا الحد؛ لأنّهم جعلوا هذا الشرط مقيسًا بين كل معطوفين اشتركا في المعنى، وبين المفعول معه؛ لأنّهّه لم يشترك مع ما قبله

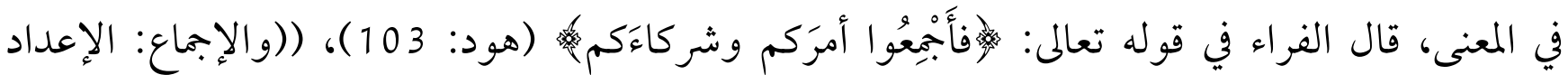
والعزيمة عَلَى الأمر . ونصبت الشركاء بفعل مضمر كأنك قلت: فأجمعو ا أمركم وادعو اشر كاءكم)(26)، وهذا عكس ما ذهب إليه أبو علي الفارسي تمامًا، إذ قال: ((جميع باب المفعول معه الواقع فيه الواو بمعنى (مَعَ) وإنّما وقعت الواو بمعناها لما بينها من المقاربة في المعنى؛ وذلك أنّ معنى (مَعَ): المصاحبة، ومعنى الواو الاجتماع، والمصاحبة ضربُ منه، فهذا وقوع الواو للاجتماع مُعَسَّى من العطف، والدليل على أنهّا معرَّاة منه أنهّا لمُمُدخِل الاسم الذي بعدها في إعراب الاسم الذي قبلها كما تدخله في إعرابه في نحو: جاءَ زيدٌ وعمروٌ، ومن هذا الباب قوله تعالى: (فأَجْعِوُوا أمرَكم وشركاءَكم)، قال أبو العباس: المعنى: مع شركِئكم، فالواو فيها بمعنى 
(مَعَ)، لأنه لا يقال: أجمعت قومي وشركائي، إنها يقال: جمعتُ قومي وشركائي)(27)، والذي أراه أنّ الكوفيين هنا أعملوا نوعين من القياس حتى وصلوا إلى هذه النتيجة، وهما قياس العلّة بأن جعلوا العطف في الأول مقيساً، والقياس الثاني قياس العكس بعد رفع الشرط، وهذه الطريقة تكثر عند الأصوليين وتسمى: تخلف الشرط . أمّا البصريون فقد أعملوا الشرط كثيرًا كذلك لكنّهم جعلوه كالقاصر في موضعه لا يتعدّاه إلى غيره، أي: إنّهم منعوا تكرار الشرط نفسه في قاعدة معيّنة على قاعدة أخرى، وأرى أنّ السبب في ذلك كثرة الاقيسة عندهم، والتحري خشية الوقوع في المانع، ومن المسائل التي احترزوا فيها من المانع مع وجود الشرط وصحته:

\section{جواز الخروج عن الاصل:}

و الشرط الذي وضعوه مفارقته من جهة واحدة، والاحتراز الذي وضعوه أن لا يؤدي في خروجه عن أصله إلى ارتكاب ضعفين معًا، ويفهم هذا من مجيء (أي) الموصولة مرة معربة، ومرة مبنية، فعندما تكون معربة فإنّ العائد يكون في صلتها، وعندما تكون مبنية فإنهّا فقدت العائد، فالمعربة فيها ضعف واحد عندهم وهو أنّ الاصل في الاسماء الموصولة البناء والضعف الحاصل هنا هو خروجها عن مثيلاتها المبنيات، وأمّا المبنية ففيها ضعف واحد كذلك وهو عدم وجود العائد، فلو أُعربت لأصبح فيها ضعفان، حذف العائد والإعراب، فقد جعلوا المبنية ضعيفة من جهة واحدة لاجتتاع الشرط والاحتراز وهو خروجها عن نظائرها(28). وأرى أنّ رأيهم هذا فيه نظر من جهتين: إحداهما: كون البناء في الاسماء ليس أصيلًا، بل هو فرع. والأخرى: علّة التنبيه؛ لأنّ نظيرتها وهي الاستفهامية معربة والشرطية كذلك؛ للتنبيه على أنّ الاصل في الاسماء الإعراب، فلو أنّهم جعلو اوجوب البناء في الموصولة بشرط ملازمة الاضافة لكان أصح، ولا يرد عليهم ما في الاستفهامية والشرطية؛ لاختلاف الجهة، و الله أعلم. ومن المسائل كذلك: 


\section{استـحقاق كل لفظ للعهمل بصـاحبه:}

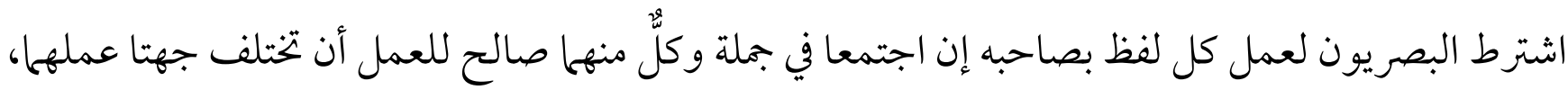

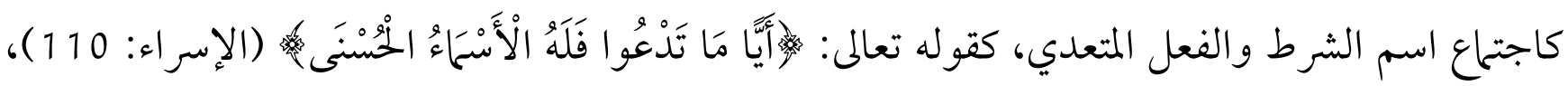
فاسم الشرط اختلفت جهة عمله عن الفعل المتعدي، وصحّ لاختلاف الجهتين، وفي هذا ردّ على الكوفيين في قولمم بالترافع بين المبتدأ والخبر، والمقصود أنّهم جعلوا الاشتراك في المعنى شرطًا لعمل كلٍ في صاحبه كما

من ذلك جواز مجيء بعض الحروف زائدة، ولم يجعلوا الشروط عامّة، بل لكل حرف زائد شروطًا تختلف عن

$$
\begin{aligned}
& \text { شروط الحروف الأخرى، من ذلك زيادة (من)، نحو : ما جاءني من أحد، هي: } \\
& \text { أحدها: أن يكون الكالام غير موجب، وهو النفي والنهي والاستفهام. } \\
& \text { والآخر : أن يكون المجرور بها نكرة(29). }
\end{aligned}
$$

والذي يُفهم من كلامي المبرد وابن السراج عند تعليلها كون هذين الشرطين إرادة الجنس كلّه وشموله، قال المبرد: ((وذلك قولك: ما جاءني من أحد إلاّ زيد، على البدل؛ لأنّ من زائدة، وإنّما تزاد في النفي ولا تقع في الإيجاب زائدة، لأنّ المنفي المنكور يقع واحده في معنى الجميع، فتدخل من لإبانة هذا المعنى، وذلك قولك: ما جاءني رجل، فيجوز أن تعني: رجلاً واحدًا، وتقع المعرفة في هذا الموضع تقول: ما جاءني عبد الله، فإذا قلت: ما جاءني من رجل، لم يقع ذلك إلا للجنس كله، ولو وضعت في موضع هذا المنكور معروفًا لم يجز لو قلت: ما جاءني من عبد الله، كان محالًا لأنّه معروف بعينه فلا يشيع في الجنس، فإذا قلت: جاءني لم تقع من ها هنا زائدة، لأنّ معنى الجميع ها هنا متنع؛ لإحاطته بالناس أجمعين، كما كان هناك نفيًا لجميعهم)((30)، والاحتراز الذي وضعوه على الشرط الثاني هو الشرط الأول هو أن يسبقها الكلام غير موجب؛ لأنّه قد توجد (من) تبعيضية وييجوز أن تكون زائدة، كقول سيبويه: (وذلك قولك: ويحَه رجلاً، ولله درّه رجلاً، وحسبّك به رجلاً، وما أشبه ذلك، وإن شئت قلت: ويحَه من رجلٍ، وحسبَك به من رجل، ولله درُّه من رجل، فتدخل من ههنا

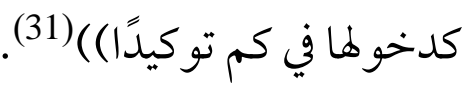


لكنّهم لم يقولو ا: إن من شروط زيادتها أنْ لا يؤدي في حذفها إخلال بالمعنى؛ لأنّ هذا الشرط تشترك فيه كثير من الحروف الزائدة، وكذلك الجممل الاعتراضية، نحو: ليس زيد بقائمة، وغيرها.

\section{المبحث الثاني : المواضع التي جاء فيها شرط أو أكثر:}

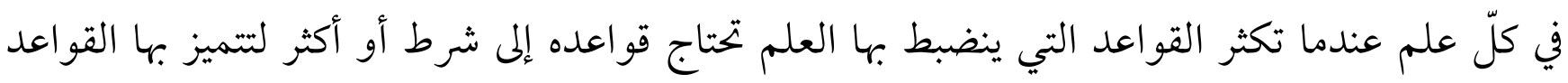

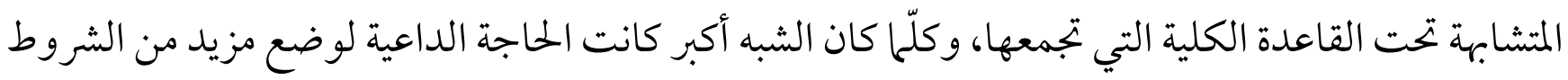

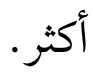

ومن الشروط التي وضعت على القو اعد النحوية:

\section{-1 - ما وضع له شـرط واحد: \\ وجوب حذف خبر المبتدأ فِ القسهم:}

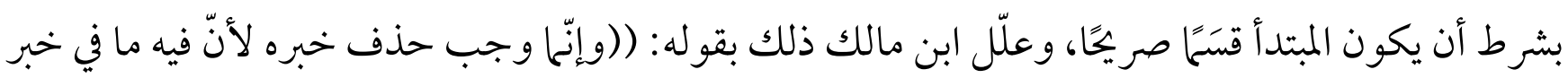

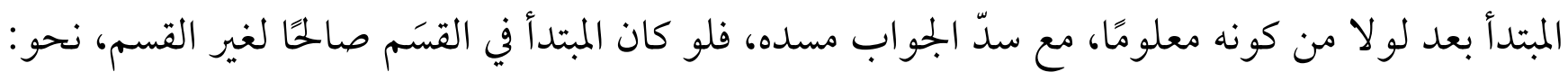
عهد الله، لم يجب الحذف، فجائز أن يقال: عليّ عهد الله لأفعلن، فيؤتى بالخبر، وجائز أن يقال: عهد الله

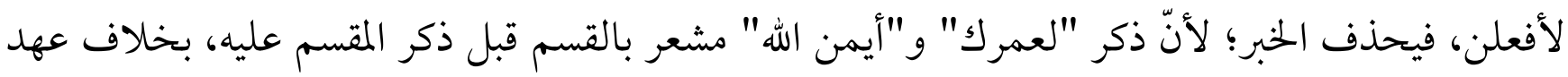

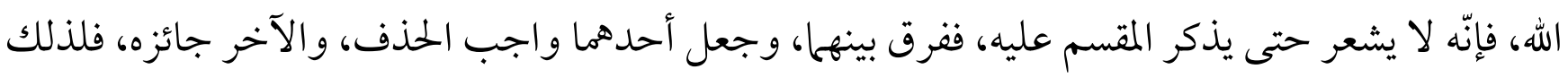

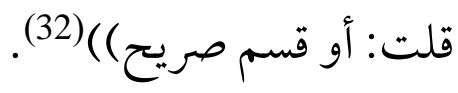

\section{جمع المصدر:}

أجاز السيرافي جمع المصدر (33)، من غير قيد أو شرط، واشترط السهيلي في جمعه أن يكون مضافًا إلى جمع، نحو:

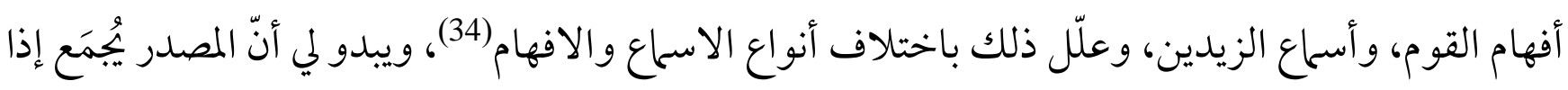
قُصِد به الاختلاف في نوع المصدر الواحد (35). 


\section{جواز الفصل بين جملتين متعاطفتين بالشرط أو الظن:}

أجازه الرضي ((بشرط ألا يكون العاطف الفاء أو الواو؛ لكونها على حرف واحد فلا ينفصلان عن معطوفيها، ولا (أم)؛ لأنّ (أم) العاطفة أي المتصلة، يليها مثل ما يلي همزة الاستفهام التي قبلها في الأغلب)(36)، نحو: أكرم زيدًا ثم إن أكرمتني عمرًا، وبالظنّ، نحو: خرج زيد أو أظنّ عمرو. وقد يقع الخلاف في الشرط تبعًا للاختلاف في قاعدته، جواز نصب ميز (كم) الاستفهامية وجرّه:

\section{جواز جرّ تهييز (كم) الاستفهاميّة حملاً على الخبريّة :}

اختلف العلم)ء فيها على ثلاثة مذاهب: الأول: أنّه لا يجيوز.

و الثّاني: أنّه يجيوز مطلَقًا، و إليه ذهب الفرّاء، والزّجّاج، و السّبرافيّ(37). والثّالث: أنّه يجوز بشرط أن يدخل على (كم) حرف جرّ، نحو: (على كم جذع بيتك مبنيّ؟)، وهو مذهب سيبويه والخليل (38). وهذا من شروط الأسباب كون الشرط هنا سببًا لازمًا في صحّة العطف، وفي تغيير العاطف لا تصحّ الجملة.

\section{جواز حذف الجار والمجرور من أفعل التعجب:}

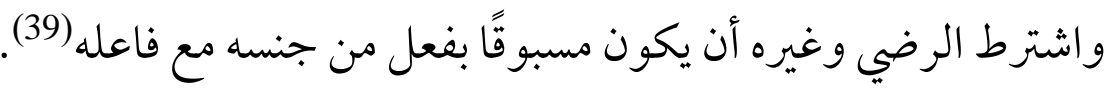
لكن المرادي جعل الحذف من قبيل الأسباب لا من حيث الشرط، واختلط عليه الامر هنا، إذ قال: (ومثاله

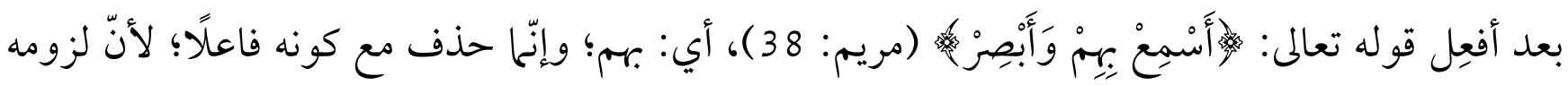
للجرّ كساه صورة الفضلة)(40)، ويبدو لي أنّ كسوّ الفاعل صورة الفضلة هذا من الأسباب، وسبب ذلك لزومه حال الجر في هذه الصيغة حصرًا؛؛ لأنّ بزوال الصيغة تزال صيغة الفاعل، وبقاء الفاعل بصورة الجرّ موقوف ببقاء صيغة التعجب.

ويبدو أنّ المر ادي تنبّه إلى هذا بعد أن ذكره، ومن ثَّم ذكر الشرط في جواز الحذف، وقد ورد الحذف من غير أن يتقدمه مثله فمن الأولى أن يُحذف إذا تقدمه مثله، كما في قول الشاعر (41): 
فذلك إنْ يلقَ المنية يلقها ميدًا وإن يستغن يوما فأجدر

$$
\begin{aligned}
& \text { 2- ما وضع له أكثر من شرط: } \\
& \text { وهذه الشروط مجتمعة وليست متفرقة، من ذلك: } \\
& \text { إعمال (لات) عمل ذيس: } \\
& \text { يكاد يُجمِع النحويون على أنّ (لات) تعمل عمل (ليس) بشر طين: } \\
& \text { أحدهما: أن يكون أحد معموليها مضمرًا، و الأكثر اسمها. } \\
& \text { والآخر: أن يكون أحد معموليها من ألفاظ الوقت(42). }
\end{aligned}
$$

ولي على شرطيها وقفة؛ لأنّ هذين الشرطين ممكن أن تُعَد من الشروط العامة، ويمكن أن تُعْد من شروط الأسباب، وإن كان الأول أرجح.

فإن قلنا: إنها عملت قياساً على (ليس)، فستكون فرعًا عنها، ولا يستوي الفرع مع الاصل فجُعِل الشرطان،

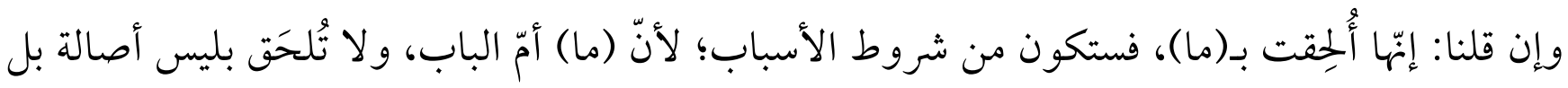
بسبب وجود (ما) عاماًَ أصيلًا لها، والقول الأول أولى؛ لبساطته؛ لأنّ (ما) عندما أعملت عمل (ليس)، وُضِعت عليها بعض الشروط كذلك، وهي غير موجودة في (لات)، وهنا ظهر الفارق بينها. ومن ذلك ما نُسِب إلى الكوفيين خطاً: لا يجوز إبدال النكرة من المعرفة إلا بشرطين: الأول: اتحاد اللفظين بين النكرة و المعرفة. و الثاني: وكون النكرة موصوفة(43).

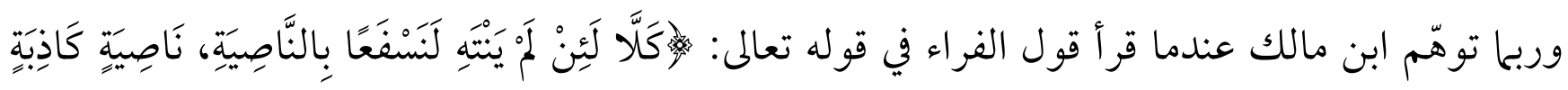

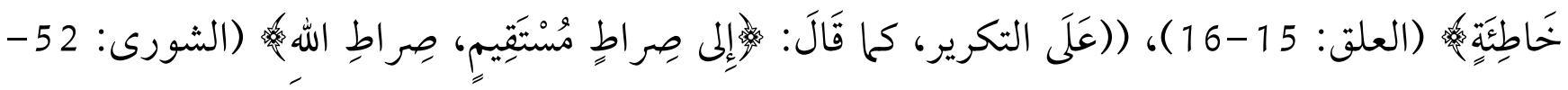
3 5 )، المعرفة تُردعَلَى النكرة بالتكرير، والنكرة عَلَى المعرفة))(44)، وأكّد المرادي أنّ كلام الكوفيين غير ذلك، إذ قال: ((كذلك نقل المصنف. ونقل غيره اشتراط الأول من الشرطين عن نحاة بغداد لا عن نحاة الكوفة، 
وكلام أهل الكوفة يدل على عدم اشتراطها ووافقهم على اشتراط الثاني طائفة من المتأخرين، وحكي عن الكوفيين أيضًا اشتر اط اتحاد اللفظ في بدل المعرفة من النكرة))(45). ومن ذلك: وجوب إضمار الناصب للمفعول المطلق، واشترطو اله شرطين هما: أحدهما: أن يكون المصدر و اقعًا بعد جملة تامة، نحو: قيامُه قيام الابطال. الثاني: كون الفعل الموافق للمصدر غير مذكور فيها، نحو : له بُكاء بكاء الثكلى (46). أمّا الشرط الأول فإنّ فيه احترازًا من وقوع المفرد موقع الجملة، قال سيبويه: (لأنّ هذا ابتداء، فالذي يبنى على الابتداء بمنزلة الابتداء، ألا ترى أنّك تقول: زيد أخوك، فارتفاعه كارتفاع زيد أبدًا، فلمّا ابتدأه وكان محتاجًا إلى ما بعده لم يجعل بدلًا من اللفظ بيصوت، وصار كالأسم)()(47)، وأما الآخر فيرد عليه ذهبتُ انطلاق زيد؛ لأنّ سيبويه مثّل له بقوله: يصوت صوت حمار، بل إنّ تمثيله أحقّ أن يكون العامل فيه الفعل الظاهر أولى من التمثيل الذي يرد على الشرط الثاني، قال الشاطبي: (وإذا تبين أن الأرجح في قولك: ذهبت انطلاق زيد أن يكون العامل هو الفعل الظاهر، فأن يكون هو العامل في يصوت صوت حمار أحق وأولى، وقد أجاز سيبويه أن يكون صوت حمار على إضمار فعل آخر، وهو كما ترى خلاف قاعدته في كتابة: أن الواجب الحمل على الظاهر، و إن أمكن أن يكون المراد غيره، ألا ترى أنه حمل سيدا على أن عينه ياء وإن أمكن أن يكون من ساد يسود، فقال في تحقيره: سُسيْد، كديك ودُييك(48)، وبهذا استدل ابن جني على قوة أمر الظاهر عندهم فعقده أصلا يرجع إليه (49)، فكذلك ينبغي في هذا. أما المر ادف فالعذر فيه لمن قدَّر عاملا آخر أوضح)(50).

\section{مجيء (إلال) صفة بهعنى غير:}

أجاز بعض النحاة بجيء (إلا) بمعنى غير، واشترطو إجى جواز ذلك بشر طين، هما: الأول: أن يكون موصو فها جمعًا منكرًا أو شبهه.

والآخر: : إن لم يكن جمعا فواحد في معنى الجمع وذلك كان تقول (ما أقبل أحد إلا خالدّ)، أي: غير خالد. ويبدو لي أنّ الشرط الأول هو من شروط الأسباب، ويكاد الشرط هنا يكون سببًا يرد على القاعدة، وذلك

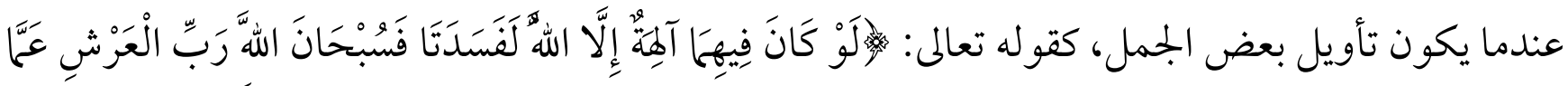


يَصِفُونَّهُ، (الأنبياء: 22)، يقول الدكتور فاضل السامرائي: ((والمعنى: غير الهه، ولا يصح أن تكون ها هنا استثناء؛ لأنّ المعنى على الاستثناء، لو كان فيها آلهة ليس فيهم الله لفسدتا، وذلك يقتضي بمفهومه أنّه لو كان فيها آلهة فيهم الله لم تفسدا وهذا باطل)(151)، وأمّا شبهه فهو أن يكون معرفًا بأل الجنسية، لأنّ الجنسية قريبة من النكرة، بخلاف العهدية، فتقول: أقبل الرجال إلا المقعدون، أي: غير المقعدين (52). أمّا الثاني فهو رأي سيبويه وطائفة من النحويين بأن يوصف بها كلّ نكرة، نحو: لو كان معنا أحد إلا عمرو لأكرمنا، بمعنى: غير عمرو (53). وقد يو جد أكثر من شرطين يردان على القاعدة النحوية، كما في:

\section{ترخيم المنادى المضاف بحذف آخر المضاف إليه: إذ منع البصريون ذلك بشروط ثلاثة، وهي:}

أحدها أصيل في هذا الضرب، وهو الاساس الذي مُنِع من أجله الترخيم أن يكون الاسم هو المنادى، كقولنا: يا آل عام، والمقصود: عامر؛ والمنادى هنا ليس عامرًا بل الآل هم المنادى. أمّا الشرطان الآخران فها لعموم المرخم بأن يكون المنادى مفردًا معرفةً، وأن يكون زائدًا على ثلاثة أحرف (54). أمّا الكوفيون فيرون جواز ترخيمه (55)، واستدلوا بشو اهد كثيرة، منها(56):

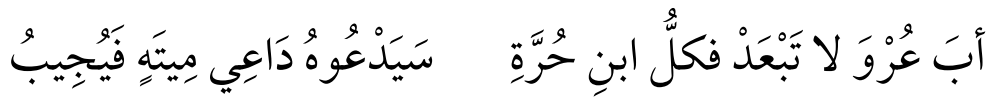

يريد: عروة، وجوّزه ابن مالك إذ قال: ((و أكثر النحويين لا يجيزون ترخيم المركب المضمن إسنادا كتأبط شرًا، وهو جائز؛ لأنّ سيبويه حكى ذلك في بعض أبواب النسب، فقال: تقول في النسب إلى تأبط شرًا: تأبطي؛ لأنّ من العرب من يقول: يا تأبط، ومنع ترخميه في باب الترخيم، فعلم بذلك أنّ منع ترخيمه كثير، وجواز ترخيمه قليل)(57)، أي: في إجازته لم يكن من موافقته للكوفيين، لكنّه نظر إلى القياس ور أى صحة ذلك. 


\section{شروط المفعول له : - لئ}

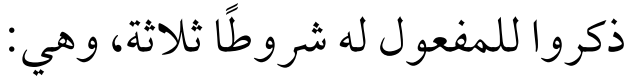

الأول: أن يكون مصدرًا.

الثاني: أن يكون فعلاً لفاعل الفعل المعلل.

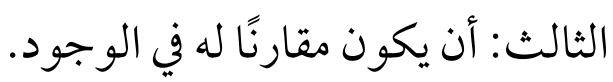

أمّا الشرط الأول فهو من شروط الأسباب؛ لأنّه علة وسبب لوقوع الفعل، وداع له، والداعي إنّا يكون حدثًا لا عينًا (58).

و أمّا الثاني فقد اشترط بعض النحاة أن يكون من الافعال الباطنة، قال أبو حيان: (وزاد بعضهم أن يكون من

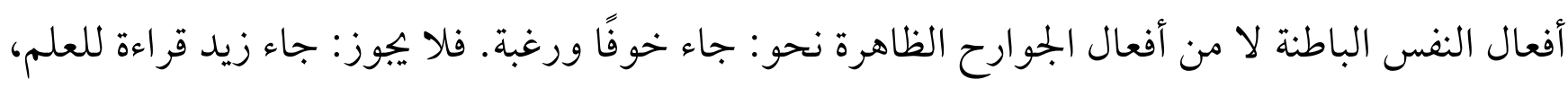
ولا قتالاً للكافر ())

وبعض النحويين أوجب أن يكون عامله من غير لفظه؛ ((المفعول له علة لوجود الفعل، والشيء لا يكون علة

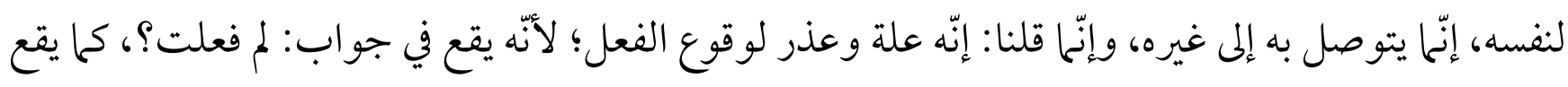

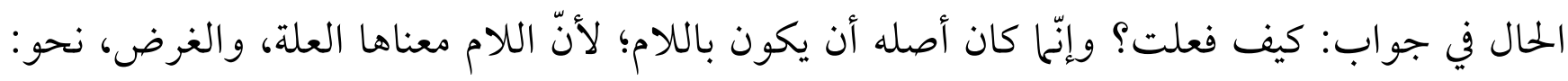
جئنك لتكرمني، وسرت لأدخل المدينة، أي: الغرض من بجيئي الإكرام، والغرض بالسير دخول المدينة،

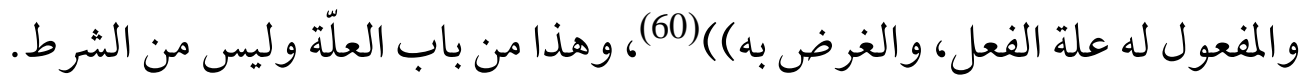
وأمّا الثالث فلأنّه علة الفعل، فلم يجز أن يخالفه في الزمان.

جواز مجيء (إذن) ناصبة للفعل المضارع:

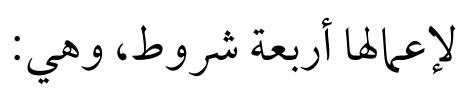
الأول: أن تكون جوابًا، أو في تقدير الجواب.

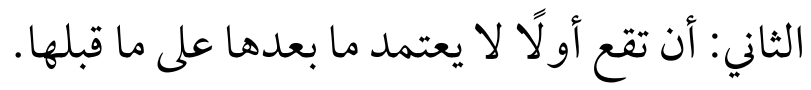
الثالث: أن لا يفصل بينها وبين معمولها بغير القسم. 
الرابع: أن يكون الفعل بعدها مستقبلًا.

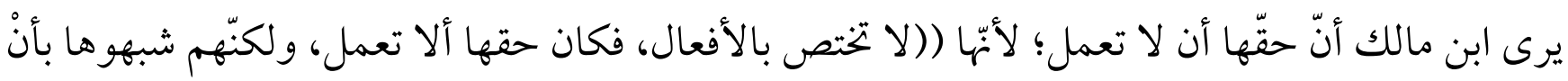
الغلبة استقبال الفعل بعدها، ولأنهّا تخرج الفعل عَّا كان عليه إلى جعله جو ابَّا، كما تخرج أن الفعل عَّا كان عليه إلى جعله في تأويل المصدر، فحملت على أن فنصبت المضارع وإن لم تختص به، كما عملت ما عمل ليس وإن لم إلم تختص بالأسماء. هذا مذهب أكثر النحويين)(أن (61).

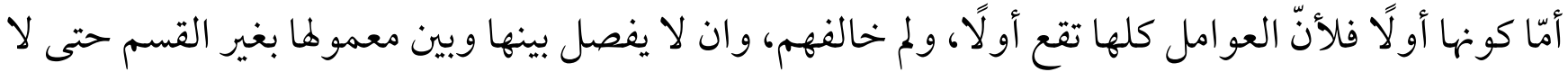

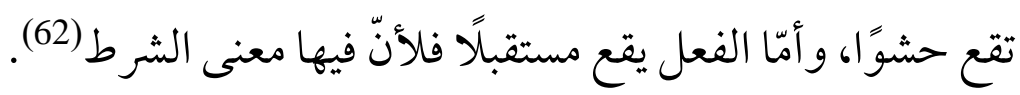

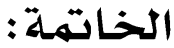

كما يُبْتَدأ بحمد الهُ وبشكره كذلك يُجْتَتَم به، والصلاة والسلام على عبده ورسوله، وعلى آله وأصحابه، وبعد: لي بعض الملاحظات سجلتها على بحثي هذا، وهي:

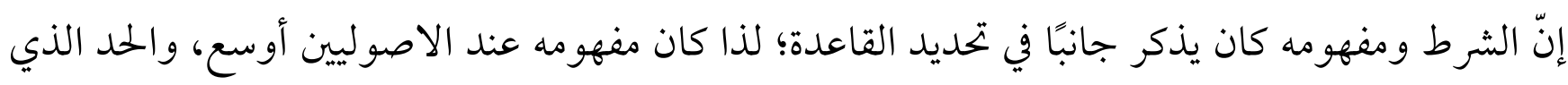
وضعوه يبيّن ذلك، إذ شمل كلّ المسائل الجزئية، وكان تطبيق الحدو والمفهوم صالحًا على القو اعد النحوية. الشروط عند النحويين نوعان شروط عامّة وشروط من الأسباب، وتركت الثفصيل فيها وبيان الفرق بينها

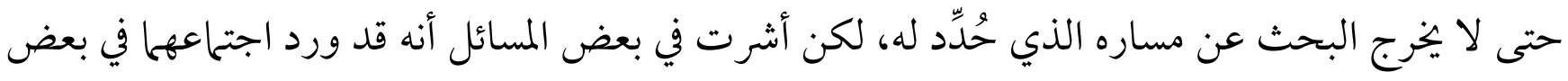
المسائل. - (n) دخل الشرط جميع المسائل النحوية؛ لأَّه مهمّ في تحديد القاعدة النحوية على الوجه الذي يحدّده المنهج الاصولي لها، وقد وقع الخلاف في الشروط كما يقع في القو اعد النحوية ومسائلها، والجزئيات التي وقع فيها الخلاف كان لها أثر في تحديد جواز الوجه النحوي أو عدمه. بناءُ على ما جاء في البحث من مادة، وعلى ما ظهر من نتائج أوصي بضرورة دراسة هذا الموضوع دراسة مستفيضة، والوقوف على مسائله، والخلاف فيه، وأثره في النحو وقواعده. 


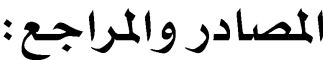

1. ابن جني، أبو الفتح عثمان بن جني الموصلي (392هـ)، الخصائص، تحقيق: د. محمد علي النجار ، دار الشؤون الثقافية، بغداد

ا ابن سيده، أبو الحسن علي بن إسماعيل بن سيده المرسي (ت458هـ)، المكم والمحيط الاعظم، تحقيق: عبد الحميد هنداوي، ط1 دار

$$
\text { الكتب العلمية ، بيروت 2000م. }
$$

ابن عقيل، بهاء الدين عبد الله بن عقيل العقيلي المصري (ت 769هـ) ، شرح ابن عقيل على ألفية ابن مالك، تحقيق: محمد محيي

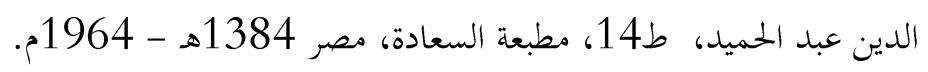

4. ابن فارس، أحمد بن فارس (ت 395ه)، معجم مقاييس اللغة، تحقيق: عبد السلام محمد هارون، مصر، دار إحياء الكتب العربية،

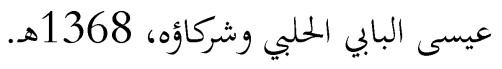

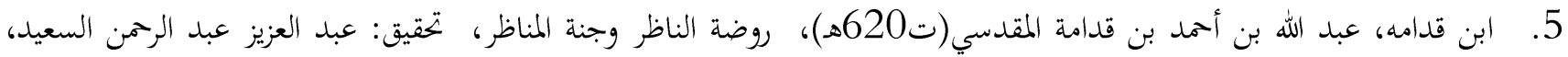

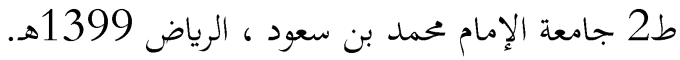

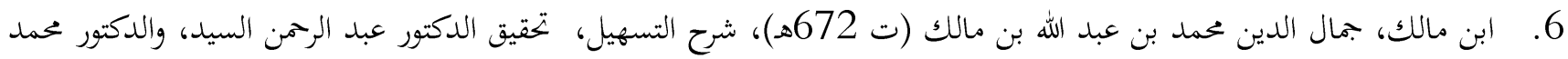

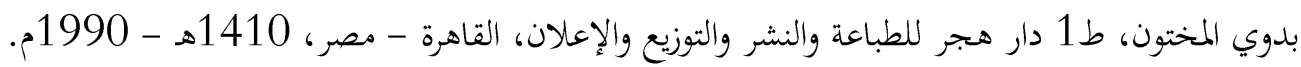

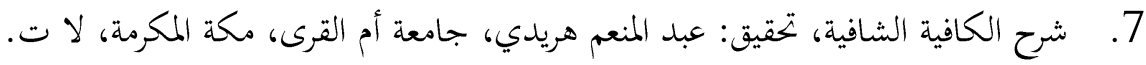

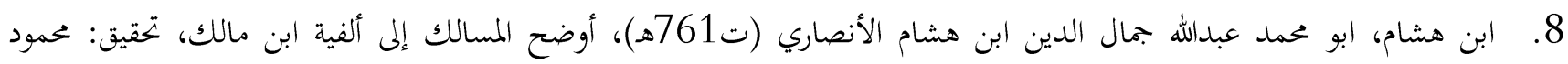

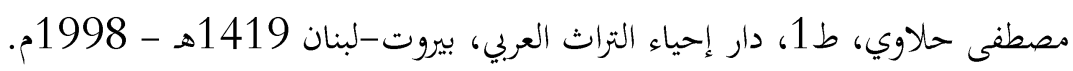

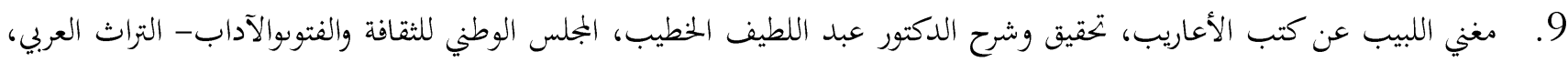

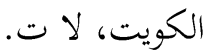

10. ابن يعيش، لبن يعيش موفق الدين يعيش بن علي بن يعيش النحوي (ت636هـ)، شرح المفصل، عالم الكتب - بيروت ، مكتبة

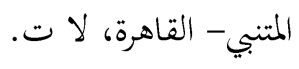

11. أبو حيان أبي حيان الأندلسي (ت 745ه)، إرتشاف الضرب من لسان العرب، تحقيق، وشرح ودراسة الدكتور رجب عثمان محمد،

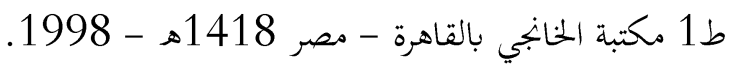

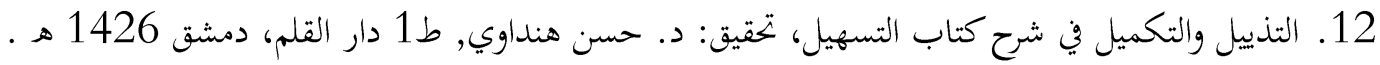

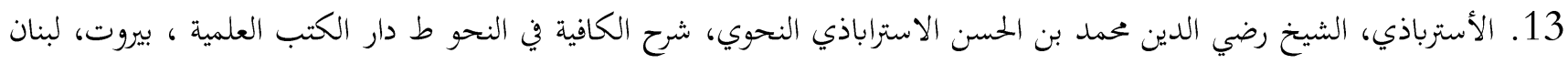

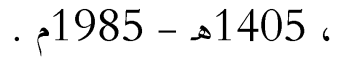

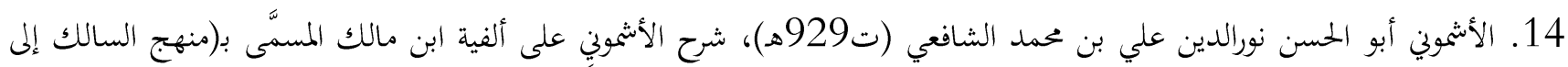

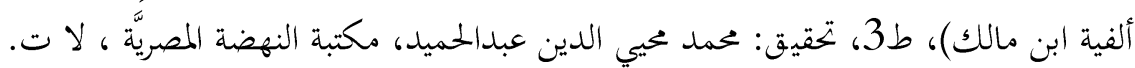

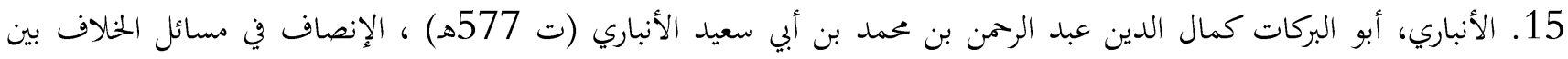

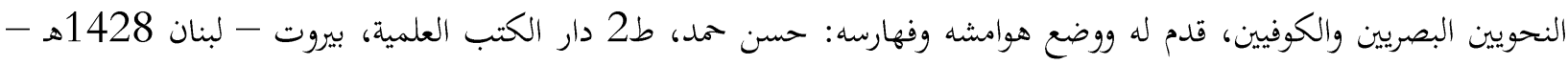


16. الأزهري ، أبو منصور محمد بن أحمد الأزهري (ت 370هـ)، تذيب اللغة، تحقيق: عبد الكريم الغرباوي، ومحمد علي النجار، مصر،

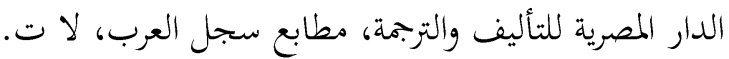

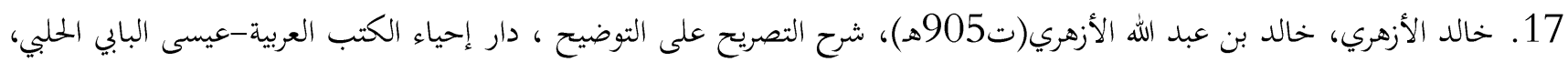
لا ت.

18. الدماميني، محمد بن أبي بكر الدماميني (ت827هـ)، تعليق الفرائد على تسهيل الفوائد, تحقيق: د. محمد عبد الرمن المفدى, ط1 بيروت 1418 هـ .

19. الزركشي،, بدر الدين بن بهادر الزركشي (ت:194هـ), تشنيف المسامع، دراسة وتحقيق: د. سيد عبد العزيز ود. عبد الله ربيع, ط1

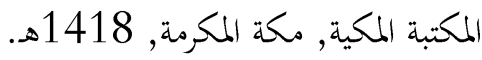

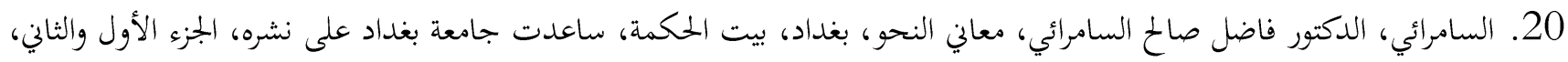

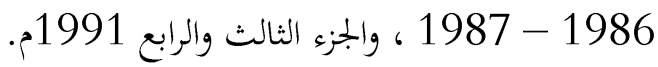

21. السراج، أبو بكر محمد بن سهل بن السراج (ت 316هـ)، الأصول في النحو، تحقيق: الدكتور عبد الحسين الفتلي، ط2 مؤسسة

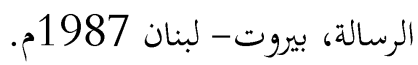

22. السعدي، عبد الحكيم عبد الرمن السعدي، مباحث العلة في القياس عند الأصوليين، دار البشائر الاسلامية للطباعة والنشر والتوزيع،

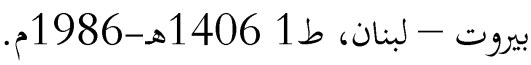

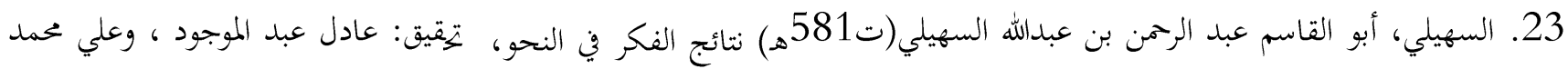

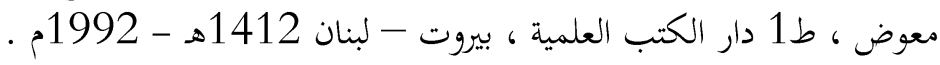

24. سيبويه، أبو بشر عمرو بن عثمان بن قنبر سيبويه (ت 180هـ)، الكتاب، تحقيق وشرح عبد السلام محمد هارون، ط1 بـ بيروت، دار الجيل، لات ات.

25. السيرافي، أبو سعيد السيرافي، الحسن بن عبد الله بن المرزبان (ت368هـ)، شرح كتاب سيبويه، تحقيق : أحمد حسن مهدلي وعلي

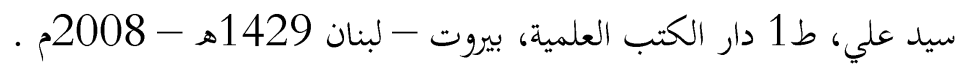

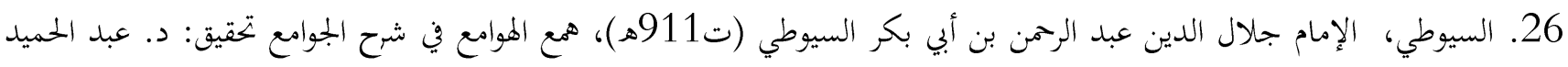

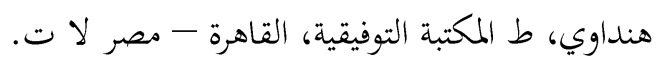

27. الشاطبي، أبو اسحاق الشاطبي، المقاصد الشافية في شرح الخلاصة الكافية، تحقيق: د. عياد الثبيتي، ط1 مكتبة دار التراث، مكة المكرمة 1417هـ.

28. الصائغ، محمد بن الحسن الصايغ(ت720هـ)، اللمحة في شرح الملحة، تحقيق: إبراهيم بن سالم الصاعدي، ط1 الجامعة الإسلامية، المدينة المنورة 1424هـ - 2004م .

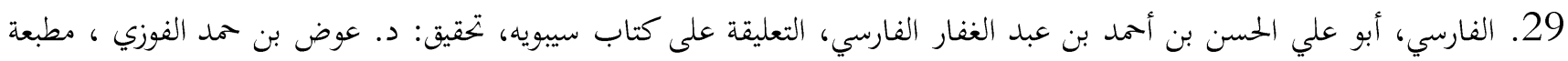

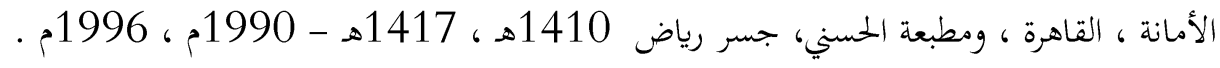

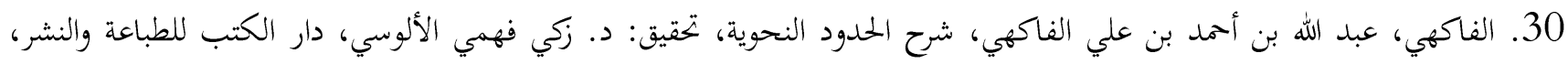
جامعة الموصل ، 1988م . 
31. الفراء، أبو زكريا يجيى بن زياد الفراء (ت207هـ)، معاني القرآن، تحقيق: أحمد يوسف نجاني، و محمد على النجار، دار السرور، لات.

32. المبرد، أبو العباس محمد بن يزيد المبرد، المتتضب، تحقيق: محمد عبد المالق عضيمة، المجلس الأعلى للشؤون الإسلامية، لجنة إحياء

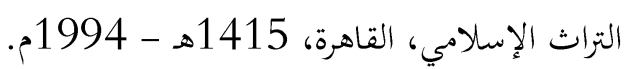

33. المرادي، الحسن بن قاسم المرادي (ت749هـ)، توضيح المقاصد والمسالك في شرح ألفية ابن مالك ، تحقيق: عبد الرمن علي بن

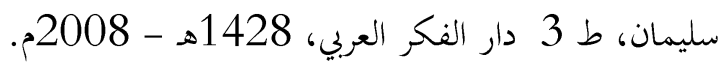

34. الجنى الداني في حروف المعاني ، تعقيق: فخر الدين قباوة ، ومحمد نديم فاضل ، ط1 دار الكترب الكتب العلمية ، بيروت 1413هـ -

35. النملة، عبد الكريم بن علي بن محمد النملة، المهذب في علم أصول الفقه، تخرير لمسائله ودراستها دراسة نظرية تطبيقية، دار الرشد -

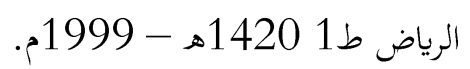

36. الورد، عروة بن الورد، الديوان، تحقيق: عبد العزيز رباح، مطبعة الإرشاد، بغداد سنة 1967م.

\section{الهوامش}

$$
\begin{aligned}
& \text { 260/3 (1) معجم مقاييس اللغة: 20 (2) } \\
& \text { (2) ينظر: المحكم: 18/ 13، } 14 \text {. } 13 \text {. }
\end{aligned}
$$

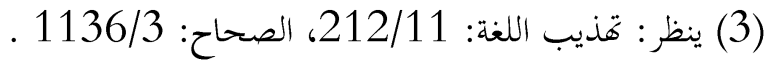

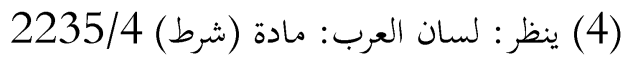

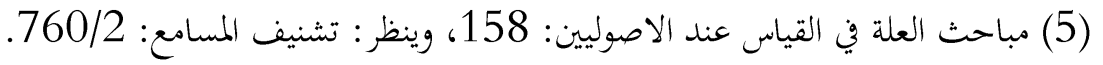

$$
\begin{aligned}
& \text { (6) تشنيف المسامع: 761/2. } \\
& \text { (7) شرح المفصل: 36/2 } \\
& \text { (8) ينظر: التذييل والتكميل: 234/9. } \\
& \text { (9) شرح التسهيل لابن مالك: 379/2 } \\
& \text { (10) تشنيف المسامع: 761/2. } \\
& \text { (11) ينظر : روضة الناظر: 84/1 } \\
& \text { 760/2 (12) تشنيف المسامع: }
\end{aligned}
$$

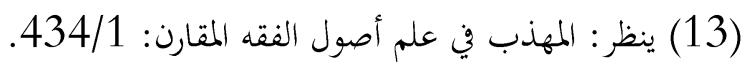

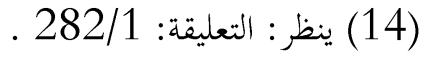

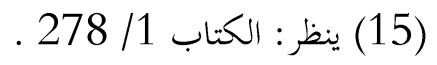

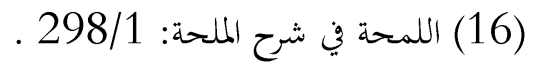




$$
\begin{aligned}
& \text { (17) شرح الحدود في النحو: } 108 \text {. }
\end{aligned}
$$

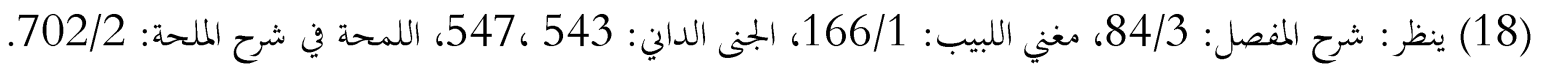

$$
\begin{aligned}
& \text { (19) ينظر: شرح المفصل: 84/3، الحدود في النحو: 459، شرح الحدود في النحو: } 108 .
\end{aligned}
$$

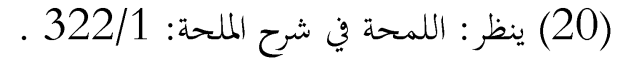

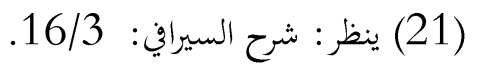

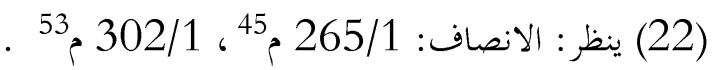

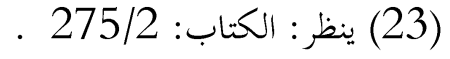

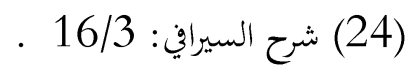

$$
\begin{aligned}
& \text { (25) من المواضع التي ذكر الفراء فيها ذلك في معانيه }
\end{aligned}
$$

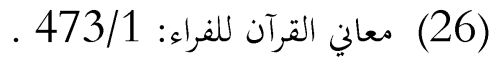

$$
\begin{aligned}
& \text { 242/4 التعليقة: 2427) }
\end{aligned}
$$

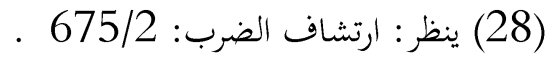

$$
\begin{aligned}
& \text { (29) ينظر: شرح الرضي: 268/4، التذييل والتكميل: 139/11. } \\
& \text { (30) المقتضب: 420/4، وينظر: الاصول في النحو: 410/1 النيط: } \\
& \text { 174/2 (31) الكتاب: 174) } \\
& \text { (32) ينظر : شرح السيرافي: 367/3. }
\end{aligned}
$$

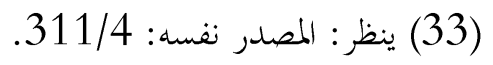

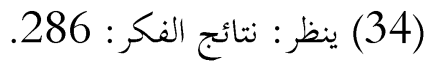

$$
\begin{aligned}
& \text { (35) ينظر : شرح التسهيل للدهاميني المعروف بـ تعليق الفرائد على تسهيل الفوائد): 39/4. }
\end{aligned}
$$

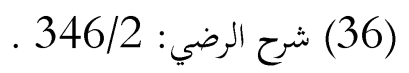

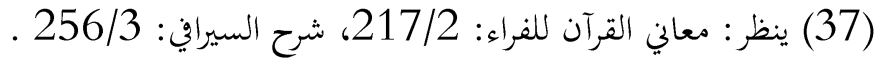

$$
\begin{aligned}
& \text { (38) ينظر: الكتاب: 159/2، 160،وشرح التسهيل: 419/2،وشرح الرضي: 96/2، الارتشاف: 37/2، 378/1، التصريح: 279/2، } \\
& \text { الهمع: 79/4، شرح الأشموني: }
\end{aligned}
$$

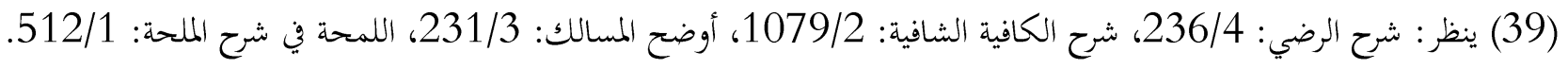

$$
\begin{aligned}
& \text { 890/2 8) }
\end{aligned}
$$

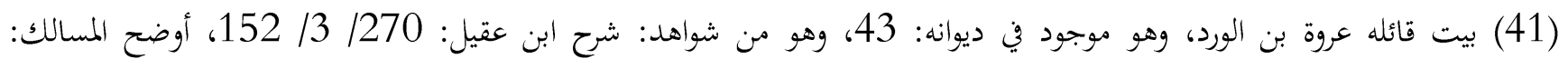

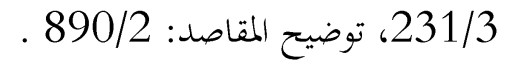

$$
\begin{aligned}
& \text { (42) ينظر على سبيل المثال: شرح الكافية الشافية 443/1، وضيح: وشرح التسهيل 377/1، وشرح ابن عقيل 295/1، والهمع 122/2، } \\
& \text { 255/1 والأشموين على سيني }
\end{aligned}
$$




$$
\begin{aligned}
& \text { (43) ينظر : شرح التسهيل: 331/3. } \\
& \text { (44) معاني القرآن للفراء: 279/3. } \\
& \text { (45) توضيح المقاصد: 1042/2 معان لفراه } \\
& \text { (46) شرح ابن عقيل: 183/2. } \\
& \text { (47) الكتاب: 366/1 انين } \\
& \text { (48) المصدر نفسه: 136/2. } \\
& \text { (49) الخصائص: 252/1. } \\
& \text { (50) المقاصد الشافية: 257/3. } \\
& \text { (51) معاني النحو: 260/2. } \\
& \text { (52) ينظر : الكتاب: 307/1، الهمع: 229/1. } \\
& \text { (53) ينظر : الكتاب: 331/2، شرح : المفصل: 307/2، المع: 30/2، الاصول: 348/1، شرح الرضي: 268/1. }
\end{aligned}
$$

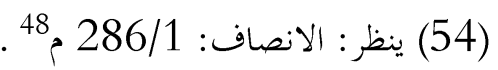

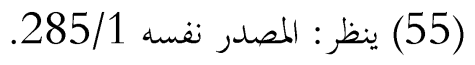

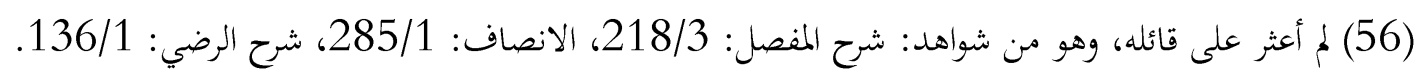

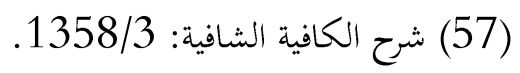

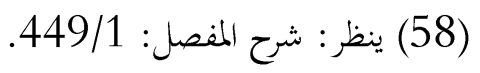

$$
\begin{aligned}
& \text { (59) ارتشاف الضرب: 1383/3، لكن هنا أجاز أبو علي الفارسي أن يكون الفعل ظاهرا، نحو: جئتك ضرب زيد، ينظر : المصدر نفسه. }
\end{aligned}
$$

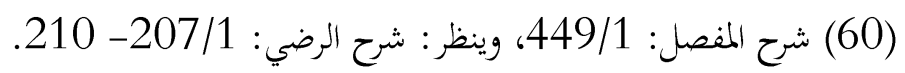

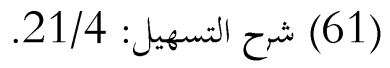

$$
\begin{aligned}
& \text { (62) ينظر: شرح المفصل: 227/4، شرح التسهيل: 21/4، اللمحة في شرح الملحة: 362/1، ارتشاف الضرب: 1653/4، الجنى } \\
& \text { الداني: } 362 .
\end{aligned}
$$

